\title{
Glucocorticoids and central nervous system inflammation
}

\author{
Klaus Dinkel, William O Ogle, and Robert M Sapolsky \\ Department of Biological Sciences, Stanford University, Stanford, California, USA
}

\begin{abstract}
Glucocorticoids (GCs) are well known for their anti-inflammatory and immunosuppressive properties in the periphery and are therefore widely and successfully used in the treatment of autoimmune diseases, chronic inflammation, or transplant rejection. This led to the assumption that GCs are uniformly anti-inflammatory in the periphery and the central nervous system (CNS). As a consequence, GCs are also used in the treatment of CNS inflammation. There is abundant evidence that an inflammatory reaction is mounted within the CNS following trauma, stroke, infection, and seizure, which can augment the brain damage. However an increasing number of studies indicate that the concept of GCs being universally immunosuppressive might be oversimplified. This article provides a review of the current literature, showing that under certain circumstances GCs might fail to have anti-inflammatory effects and sometimes even enhance inflammation. Journal of NeuroVirology (2002) 8, 513-528.
\end{abstract}

Keywords: CNS inflammation; corticosteroids; immunosuppression; neuroimmunology

\section{Stress and glucocorticoids}

Stress is the "nonspecific response of the body to any demand." This rather general definition of stress was given over 60 years ago by famous stress-pioneer H. Selye (Selye, 1936), who introduced the study of stress (Selye, 1978) as a scientific topic dealing with the physiological changes occurring in the structural and chemical composition of the body in response to a stressor (a neologism at the time, also created by Selye). A stressor is defined as a physical and/or psychological stimulus that induces these changes. Because most of the vast scientific literature shows the negative and dangerous effects of stress for the body, one could easily get the impression that the physiological systems activated by stress are generally bad and damaging in nature. Instead, stress should

Address correspondence to Dr. Klaus Dinkel, Department of Biological Sciences, Gilbert Hall, Stanford University, Stanford, CA 94305-5020, USA. E-mail: kdinkel12@hotmail.com

Work in the authors' laboratory was supported by grants from BASF and the German National Merit Foundation to KD. Funding was also provided to RMS by NIH grant R01 MH53814.

Received 14 January 2002; revised 11 May 2002; accepted 20 May 2002. be seen as one of the most important and complex adaptive bodily reactions. Stress by itself represents a threat to the body's homeostasis, but adaptation to stress confers a survival advantage. Successful adaptation, however, requires not only the ability to respond to a stressor but also to control that response appropriately.

A key mechanism in the response to acute ("fight or flight" reaction) and chronic (accumulation of minor or major day to day reactions) stressors is the activation of the hypothalamic-pituitary-adrenal (HPA) axis (Figure 1). First, the hypothalamus is stimulated to secrete the corticotrophin-releasing hormone (CRH), which after passage of the hypothalamicpituitary portal system, leads to pituitary adrenocorticotrophic hormone (ACTH) secretion into the peripheral circulation (Trainer et al, 1995). ACTH in turn triggers adrenal glucocorticoid (GC) release and production. Once GCs are secreted, approximately $90 \%$ are bound to GC-binding globulins and albumin, whereas unbound or free GCs are responsible for GC effects. The primate GC is cortisol, although most rodents secrete corticosterone from the adrenals; the plasma half-life of cortisol is 70 to 90 min (Tyrrell et al, 1994). The HPA axis is highly sensitive to everyday challenges in animals and humans (McEwen, 


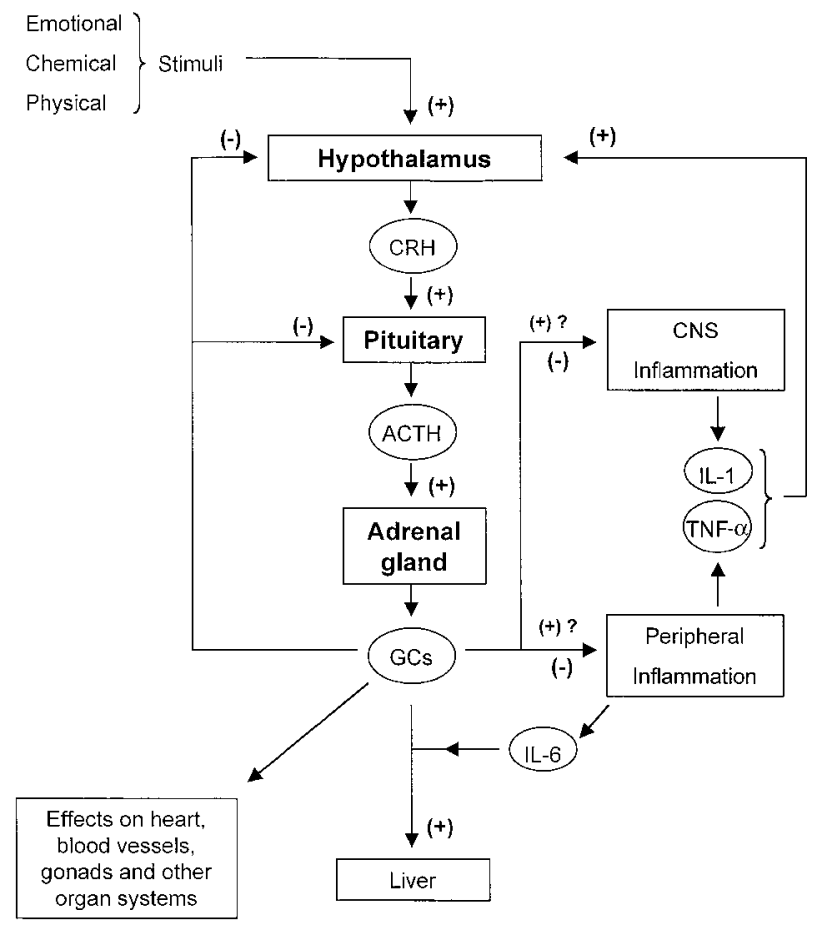

Figure 1 The HPA axis and inflammation. Various stressors can activate the HPA axis. The hypothalamus is stimulated to secrete CRH, which leads to ACTH secretion into the peripheral circulation. ACTH in turn triggers adrenal GC release and production. The CRH system is inhibited by GCs in a negative feedback loop. TNF- $\alpha$ and IL-1 are produced from inflammatory sites and are potent activators of the HPA axis. IL-6 acts synergistically with GCs to stimulate the hepatic secretion of acute phase proteins. Although GCs are widely known for their anti-inflammatory actions, "(-)," more recently also proinflammatory effects have repeatedly been reported, “(+) ?" HPA = hypothalamic-pituitary-adrenal; $\mathrm{CRH}=$ corticotrophin-releasing hormone; ACTH = adrenocorticotrophic hormone; GCs = glucocorticoids; $\mathrm{IL}=$ interleukin; $\mathrm{TNF}=$ tumor necrosis factor; $(+)=$ enhancing; $(-)=$ suppressing.

2000; Ottaviani and Franceschi, 1996). GCs, as the main effectors of the HPA axis, are released into the bloodstream and induce systemically a variety of physiological changes in different organs/organ systems of the body. For example, energy is mobilized from storage sites and energy delivery is increased in parts of the nervous system, muscles, and stressed body sites. In synergy with catecholamines, GCs increase the cardiovascular tone. Furthermore, energetically expensive and, at the very moment, nonessential processes like growth, reproduction, food uptake, and parts of the immune system are suppressed (Munck et al, 1984, 1994; McEwen et al, 1986; Sapolsky et al, 2000). An impaired stress response can have deleterious consequences: Patients with Addison's disease suffer from adrenal dysfunction, which results in failure to respond to even minor stressors (addisonian crisis) and can lead to coma or death if the patients are not treated with GCs. It has also been proposed that a disruption of the HPA axis in animals could explain increased susceptibility to autoimmune diseases (Sternberg et al, 1989; Calogero et al, 1992).
Although these GC-induced changes serve to promote homeostasis and are essential for survival, it has been found that under certain circumstances, exposure to an excess (acute and chronical) of GCs can also have serious negative side effects on various target tissues of the body. Elevated GC levels is a common feature of chronic stress, and is seen, for example, in caregivers of dementia patients, who show impaired cell-mediated immunity and thus an increased vulnerability to infection (Vedhara et al, 1999; Bauer et al, 2000). The concept of a "eucorticoid state" (Munck et al, 1984; Burchard, 2001) recognizes that neither too little (absent/impaired cortical function) nor too much GC (pharmacological dosing/hyperfunction) is beneficial.

How are GCs able to induce these rapid systemic physiological changes? First, within minutes after activation of the HPA axis, GCs are being released from the adrenal glands; second, GCs are hydrophobic molecules, which enables them to enter any cell through the hydrophobic cell membrane; and third, the intracellular cytosolic GC receptors have a widespread distribution throughout tissues. GC effects are mediated by either the high-affinity mineralcorticoid receptor (MR) or the low-affinity glucocorticoid receptor (GR) (De Kloet et al, 1998; Birnstiel et al, 1995). Binding of GCs to these receptors leads to the dissociation of a heat-shock protein from the receptor, followed by receptor dimerization, which then triggers the nuclear translocation of the ligand-receptor dimer complex. In the nucleus, the complex binds to specific DNA sequences called glucocorticoid responsive elements (GREs) and induces/facilitates transcription of the respective genes (De Bosscher et al, 2000; Boumpas et al, 1993). However, some effects may not require receptor dimerization but may occur primarily through protein-protein interactions (Kellendonk et al, 1999). The expression of an estimated $1 \%$ of genes may be regulated by GCs, which may be either up- or down-regulated. Given this large number of genes influenced by GCs, it is hardly surprising that the effects of different steroid interactions are rather complex and therefore the therapeutic use of GCs has to be carefully evaluated by consideration of beneficial versus potentially harmful effects. Regarding (neuro)inflammation, it is important to note that besides the psychological and physiological stimuli mentioned before, proinflammatory cytokines such as interleukin (IL)-1 proved to be potent stimulators of the HPA axis (Figure 1; Besedovsky et al, 1986; Berkenbosch et al, 1987; Sapolsky et al, 1987).

Because of the complex nature of the theme, this review has to integrate findings from the disciplines of neurobiology, neurendocrinology, and (neuro)immunology. By giving a broad overview of GCs, the stress response, and adaptive and maladaptive effects, we have introduced some basic concepts of endocrinology that are essential to understanding 
the even more complex mechanisms when the endocrine, nervous, and immune systems interact during central nervous system (CNS) inflammation. Before dealing with this most complicated topic, where all three physiological systems act simultaneously and influence each other, it is useful to first focus on adverse GC effects in the CNS and then on interactions between the nervous and the immune systems. After that, we consider GC effects in inflammation, thereby emphasizing possible differences between the well-characterized GC effects on peripheral inflammation and the so far much less studied GC effects on CNS inflammation. It will become clear that this review is not just merely summarizing and updating well-known anti-inflammatory GC effects, but is also showing a quite unexpected and very different side of GCs in CNS inflammation.

\section{Adverse glucocorticoid effects in the central nervous system}

In the brain, GCs feed back negatively onto the hypothalamus (Figure 1), thereby inhibiting their own overproduction and maintaining homeostasis (Jacobson and Sapolsky, 1991; Lilly and Gann, 1992). Although most cells in the brain predominantly express GRs, principal cells of the limbic system often contain MRs as well as GRs (Joels, 2001). The hippocampus, for example, a brain part vital for learning and memory, has one of the highest GC receptor concentrations in the brain (McEwen et al, 1986; Sapolsky, 1994), and is therefore particularly sensitive to GC effects. Acute stress seems to facilitate the formation of memories of events associated with strong emotions (McGaugh, 2000; Meaney, 1988). Sustained exposure to GCs, however, seems to contribute to impairment of cognitive function and promote atrophy of brain structures such as the dendrites of pyramidal neurons in the CA3 region of the hippocampus (McEwen et al, 1995; Magarinos et al, 1999; Sapolsky, 1992). Magnetic resonance imaging studies in humans have shown that GCrelated disorders such as Cushing's disease or posttraumatic stress disorder are assocociated with atrophy of the whole hippocampus (Sapolsky, 1996; McEwen and Magarinos, 1997). However, it is not known whether the loss of total volume is due to the atrophy of the dendrites on a cellular level. GCs have also been found to inhibit neurogenesis in the dentate gyrus of the hippocampus (Gould et al, 1997, 1998). There have been reports that stress lasting many months or years can kill hippocampal neurons directly (Landfield et al, 1981; Sapolsky et al, 1985); it remains unclear whether this is a physiological or pharmacological effect.

A few days of stress/GC exposure does not kill the neurons but has been shown to impair the capacity of neurons to survive during a neurological insult, such as ischemia, trauma, seizure, exposure to gp 120, oxygen radicals, or beta-amyloid, and eventually exacerbates the resulting neuropathological damage (Sapolsky and Pulsinelli, 1985; Sapolsky, 1985; Koide et al, 1986; Miller and Davis, 1991; Stein-Behrens et al, 1992). In these neurological disorders, the injury and death of neurons is caused at least in part by overstimulation of receptors for excitatory neurotransmitters such as glutamate (Whetsell, 1996; Beal, 1992; Lipton and Rosenberg, 1994). A massive increase of extracellular glutamate results in prolonged depolarization of neurons, inducing further glutamate release and in turn increase in intracellular $\mathrm{Ca}^{2+}$-levels, which then activates $\mathrm{Ca}^{2+}$ dependent enzymes (e.g., proteases degrading the cytoskeleton), and eventually leading to neuronal cell death. This pathophysiological mechanism is called excitotoxicity (Olney, 1978) and involves a complex series of events over time (Figure 2). GCs have been found to exacerbate the extent of neurological necrotic cell death. A variety of different primary physiological GC effects on neurons have been identified that could contribute to the overall "endangering" effect: (1) Interfering with neuronal

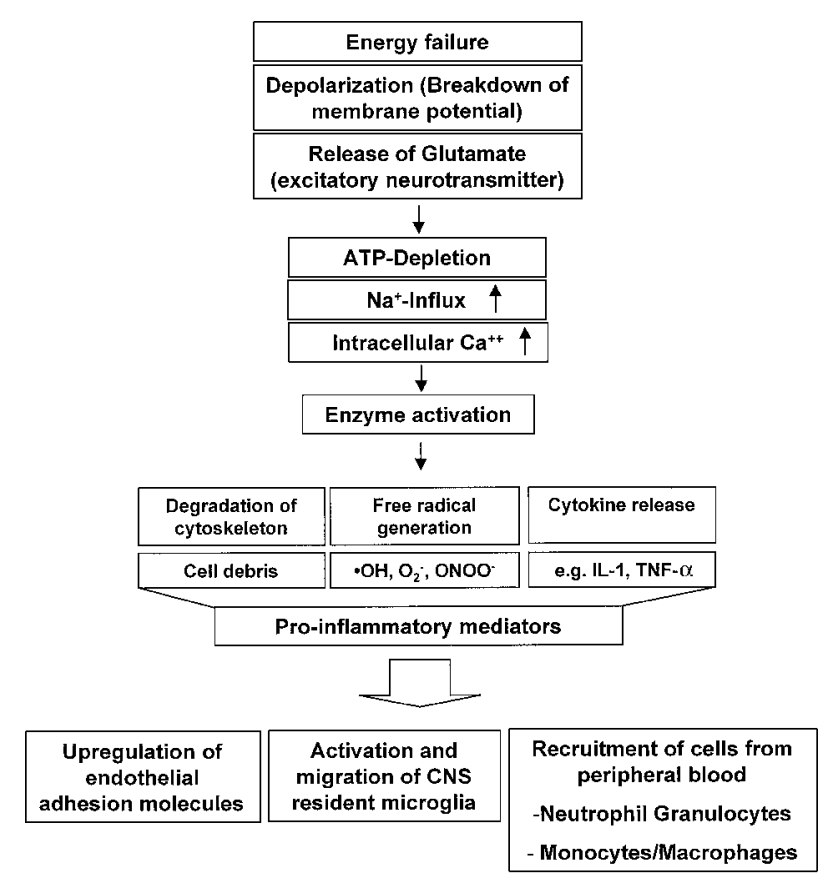

Figure 2 Excitotoxic brain injury and inflammation. Energy failure leads to the depolarization of neurons, causing a massive release of excitatory neurotransmitter (e.g., glutamate). The increased extracellular glutamate results in continuous excitation of neurons, inducing further glutamate release, ATP depletion, and a dramatic increase in intracellular $\mathrm{Ca}^{2+}$ levels, which then activates $\mathrm{Ca}^{2+}$-dependent enzymes (e.g., proteases, lipases, peroxidases), and eventually leading to neuron death. Free radicals are generated, which damage membranes; injured neurons and glial cells secrete certain cytokines such as IL-1 or TNF- $\alpha$. Several of these molecules produced during brain injury (cytokines, free radicals) also act as potent inflammatory mediators, which activate microglia and lead to the infiltration of blood-borne inflammatory cells into the brain parenchyma. Na, sodium; Ca, calcium; IL, interleukin; TNF, tumor necrosis factor. 
energy metabolism (e.g., down-regulation of glucose uptake); (2) suppression of neuroprotective mechanisms (e.g., down-regulation of radical-scavenging enzymes such superoxide dismutase); and (3) exacerbation of excitotoxicity via increased synaptic glutamate concentrations and increased cytosolic calcium mobilization. Although some of these effects are secondary to the disruptive effects of GCs on neuronal energetics, some are direct and energy independent (Kerr et al, 1989; Joels and de Kloet, 1989; Bhargava et al, 2000).

In excitotoxic brain injury, a large part of neurons seem to die by necrosis. In contrast to apoptotic cell death, necrotic cells swell and burst, releasing proinflammatory mediators. As shown in Figure 2, neuronal tissue injury (e.g., caused by direct trauma, ischemia/excitotoxicity, or viral infections) also induces a well-defined inflammatory reaction in the CNS.

\section{CNS and inflammation}

The brain has long been regarded immunologically privileged because of the blood-brain barrier (Dermietzel, 1975; Risau and Wolburg, 1990), the lack of professional antigen-presenting cells, the very low expression of major histocompatibility complex (MHC) I and MHC II molecules (Wekerle et al, 1986), and the prolonged survival of tissue transplants. In fact, studies over the last 10 years proved that the immunoprivileged status of the CNS is not due to the absence of the imune system in the CNS but reflected an active process, which includes a dynamic interaction between the objectives of the imune response and the specialized needs of the CNS with its highly specialized and sensitive neurons (Ferguson and Griffith, 1997; Dalakas, 1995; Becher, 1998). This means that immune surveillance and immune function are minimal under healthy conditions but are inducible whenever required. It is important to differentiate between two major parts of the immune system: On the one hand, there is the adaptive immune system, which involves T/B lymphocytes, responsible for specific antigen recognition and longlasting protection after vaccination. This adaptive system can also be responsible for deleterious autoimmune diseases such as multiple sclerosis or bystander damage during viral or bacterial infections. On the other hand, there is the innate, nonspecific immune system, where the main players are the short-lived but fast-acting neutrophil granulocytes and longer lived macrophages. These cells migrate upon activation into the injured tissue and provide host defense by phagocytosis and release of cytotoxins. After that, these cells play also a major role in tissue remodeling and wound healing. However, an inadequate or to prolonged immune reaction might be an important factor in neurodegenerative diseases or stroke. Although being part of the innate immune system, macrophages also interact with the adaptive system by presenting antigen to T lymphocytes.

Accumulating evidence during the last decade has shown that many neurological insults and neurodegenerative disorders are also accompanied by a marked acute inflammatory reaction. This inflammation is characterized by infiltration of blood-borne granulocytes and monocytes/macrophages into the respective brain parenchyma as well as activation of CNS resident microglial cells, astrocyte swelling, and the expression of cytokines, adhesion molecules, and other inflammatory mediators (Perry and Gordon, 1991; Dirnagl et al, 1999; Feuerstein et al, 1998; Beal, 1995; Lee et al, 1999). The expression of proinflammatory transcription factors such as nuclear factor kappa B (NF- $\kappa$ B) and hypoxia-inducible factor 1 has been found to be triggered by the $\mathrm{Ca}^{2+}$-related activation of intracellular second messenger systems, the increase in oxygen free radicals, products of membrane peroxidation, and deprivation of oxygen and nutrients (O'Neill and Kaltschmidt, 1997; Ruscher et al, 1998). Consequently, the injured brain cells produce proinflammatory cytokines like IL-1 $\alpha$, IL$1 \beta$, or tumor necrosis factor alpha (TNF- $\alpha$ ) (Rothwell et al, 1996). Adhesion molecules such as intercellular adhesion molecule-1 (ICAM-1) are up-regulated on endothelial cells of the CNS microvasculature and interact with surface receptors (e.g., lymphocyte function-associated antigen [LFA-1]) on neutrophils in the bloodstream. The neutrophils adhere to the endothelium, migrate through the vascular wall and into the tissue (diapedesis). Macrophages are usually the second wave of tissue-infiltrating cells after the neutrophils (Iadecola, 1997). Recruitment of these peripheral immune cells, as well as migration of microglia, are regulated by chemokines such as monocyte chemoattractant protein (MCP-1), which are expressed by astrocytes (Ransohoff and Tani, 1998), or the neuron-derived chemokine fractalkine (Chapman et al, 2000). There is considerable evidence that the inflammation is contributing significantly to the developing brain damage by such mechanisms as releasing neurotoxic substances, such as cytokines or free radicals (Beal, 1995; Barone and Feuerstein, 1999; McGeer and McGeer, 1999; Sanderson et al, 1999; Vila et al, 2000). In experimental models of stroke, inflammation seems to contribute to cerebral ischemic injury (Becker, 2001). The importance of inflammatory reaction in the pathogenesis of brain injury has been reviewed previously (Feuerstein et al, 1998; Stoll et al, 1998; del Zoppo et al, 2001). The role of inflammation in brain injury, however, is a controversial subject in neurology because a growing number of recent studies suggest that the impact of inflammatory mediators may actually be beneficial in the recovery from brain damage (Feuerstein and Wang, 2001; Schwartz and Moalem, 2001; Kerschensteiner et al, 1999; Rapalino et al, 1998). The imune response 
at the right time and extent certainly could serve an important function in tissue reconstruction and remodeling, just as it does in the process of woundhealing in the periphery. This is reflected in the controversial literature about the role of proinflammatory cytokines in stroke or seizures, being either neurotoxic or neuroprotective (Yoles et al, 2001). For example, mice overexpressing IL-6 and TNF- $\alpha$ in glia develop both seizures and neurodegeneration (Campbell et al, 1993; Akassoglou et al, 1997), on the other hand, mice lacking TNF- $\alpha$ receptors sustain larger infarcts than wild-type mice (Bruce et al, 1996; Cheng et al, 1994; Gary et al, 1998). A clinical trial using a monoclonal antibody to ICAM-1 (Enlimomab Study) aiming at shutting down the inflammatory response after brain injury has failed to deliver any beneficial effect in stroke patients (DeGraba and Pettigrew, 2000; De Keyser et al, 1999). Recent data (Iadecola and Alexander, 2001), however, indicate that immune activation induced by the heterologous protein as well as insufficient preclinical data may have played an important role in the failure of this trial. In summary, even though the understanding of role of inflammation might have to be modidfied under certain circumstances, there is still overwhelming evidence that proinflammatory mediators do play an important part at certain stages of brain injury and contribute to the developing damage.

The innate immune sytem, with its ability to promote a fast, acute inflamation at target sites, seems also to play an important role in the pathogenesis of Alzheimer's disease and other neurodegenerative disorders (McGeer and McGeer, 1994, 1995, 1999). Large numbers of reactive microglia have been identified in CNS lesions. Microglia represent the phagocytic system of the brain, very similar to the blood-borne macrophages, and release upon stimulation potentially neurotoxic products such as excess glutamate or free radicals (respiratory burst) (Banati et al, 1993; Kreutzberg, 1996; Neumann, 2001). Neuronal populations in close proximity to activated microglia are exposed to proinflammatory molecules such as IL- $1 \alpha$ (Walker et al, 1995), TNF- $\alpha$ (Hetier et al, 1991), and superoxide anions (Colton et al, 1996). The important role of inflamation was confirmed by studies investigating kainic acid-induced cell death (Akiyama et al, 1994), animal models of acute cerebral ischemia (DeGraba, 1998; Nogawa et al, 1997; Feuerstein et al, 1998), stroke (Beamer et al, 1998; Becker, 1998), and acquired immunodeficiency syndrome (AIDS)related dementia (Adamson et al, 1996; Griffin et al, 1994). Therefore inflammation has been attributed to wide aspects of secondary injury phenomena, such as lipid peroxidation, free radical production, and edema formation. According to these findings, antiinflammatory drugs should have a beneficial effect in the context of a neurological insult; suppression or inhibition of the immune response should ameliorate the neuronal tissue damage. As discussed later in this review, GCs did not prove to be very suc- cessful in the treatment of a variety of neurological insults.

\section{Glucocorticoids and inflammation: Challenging the dogma}

Glucocorticoids have been used widely for the treatment of diseases associated with activation of the immune system since their original application in the late 1940s (Hench et al, 1949). This work was awarded the Nobel Prize for medicine and provided the foundation for the dogma that GCs are uniformly immunosuppressive. The use of GCs in the treatment of various clinical disorders such as autoimmune diseases, chronic inflammation, or transplant rejection has been proven successful. The therapeutic value of GCs is attributed to their potent anti-inflammatory and immunomodulatory effects (Table 1, anti-inflammatory effects) on T-cell activation, adhesion molecule expression, cell migration, and cytokine production (Cato and Wade, 1996). GCmediated reduction of leukocyte infiltrate, for example, occurs via the down-regulation of adhesion molecules, such as ICAM-1, endothelial-leukocyte adhesion molecules (ELAM-1), and vascular cellular adhesion molecule (VCAM-1) (Cronstein et al, 1992). In addition, monocyte and neutrophil recruitment during acute inflammation has been found to be under the negative modulatory control of the GC-induced lipocortin-1 (Getting et al, 1997). This clearly shows that GCs have anti-inflammatory effects in the periphery.

GCs have also been used to treat inflammatory diseases within the CNS, such as edema arising from brain tumors (Barnes and Adcock, 1993; Galicich et al, 1961), viral encephalitis, bacterial meningitis (Coyle, 1999), or to improve recovery from acute exacerbation in multiple sclerosis patients (Fillipini, 2000). Patients with malignant brain tumors are often treated with GCs to reduce vasogenic brain edema. In about $50 \%$ of cases, all clinical signs disappear (Vecht, 1998); however, GC treatment seems to provide a survival advantage to both normal and tumor cell types (Newton et al, 2001). Even low doses of dexamethasone were found to inhibit significantly the infiltration of brain tumors by lymphocytes and microglia (Badie et al, 2000), thus suppressing the cellular immunity against the tumor. The findings in these cases, showing that GCs also had anti-inflammatory effects in the CNS, gave rise to the assumption that GCs should be uniformly anti-inflammatory in all kinds of different CNS injuries, including hypoxiaischemia and seizure. Accordingly, GCs should ameliorate damage during these neurological insults by suppressing the acute inflammation; but instead, as mentioned before, GCs have been found to increase neuron loss. Given the assumed anti-inflammatory properties of GCs in these neurological insults, the most likely explanation for these seemingly contradictory findings would be that the harmful GC effects on neuronal survival ability simply outweigh the 
Table 1 Glucocorticoid effects on inflammation

\begin{tabular}{ll}
\hline Anti-inflammatory & \\
\hline $\begin{array}{l}\text { Lymphocytes (adaptive) } \\
\text { Decreased cytokine-induced proliferation }\end{array}$ & Enhanced immunglobulin synthesis \\
Decreased cytotoxicity & \\
Decreased cytokine production (IL-1, IL-2) & \\
Induction of apoptosis (Lymphopenia) & \\
Neutrophil granulocytes (innate) & Peripheral neutrophilia (mobilization of the "bone marrow reserve") \\
Decreased extravasation & Delayed apoptosis \\
Decreased adhesion molecule expression & \\
Decreased phagocytosis & \\
Decreased free radical generation & \\
Decreased chemotaxis & \\
Macrophages/monocytes (innate, adaptive) & Induction of macrophage migration inhibitory factor (MIF) expression \\
Decreased extravasation & \\
Inhibition of differentiation & \\
Decreased phagocytosis & \\
Decreased MHC I and II expression & \\
Decreased antigen presentation & \\
Miscellanous & \\
Decreased adhesion molecule expression (e.g., & Potentiation of acute phase reaction (liver) \\
ICAM-1, VCAM-1) & \\
Decreased pro-inflammatory cytokine production & Increased pro-inflammatory cytokine receptor expression (e.g., IL-1 receptor) \\
(e.g., IL-1 $\alpha / \beta$, TNF- $\alpha$, IL-6, IL-2) & \\
Inhibition of cyclooxygenase-2 synthesis (COX-2) & Improved woundhealing \\
& Stimulation of 5-lipoxygenase expression \\
\hline
\end{tabular}

${ }^{a}$ References by first authors: Marx, 1995; Kern, 1988; Goulding, 1998; Perretti, 1994; Chrousos, 1995; Zuckerman, 1989; Barber, 1993; Burchard, 2001; Mukaida, 1991; Bailey, 1988.

${ }^{\mathrm{b}}$ References by first authors: Burton, 1995; Cox, 1997; Wiegers, 1998; Wilckens, 1997; Chrousos, 1995; Davis, 1991; Donnelly, 1997; Liles, 1995; Calandra, 1995.

protective anti-inflammatory effects. There is, however, another possible explanation. During the past decade, numerous studies have shown that GCs can also have stimulatory or permissive effects on immune function (see Table 1, proinflammatory effects), suggesting that the current concept of uniformly antiinflammatory GC effects is an oversimplification of GC physiology and needs to be extended.

GCs have been shown to act synergistically with exogenously added cytokines in the periphery. In hepatic cell cultures (Baumann and Gauldie, 1995) as well as in rats (Nishio et al, 1993), GCs strongly potentiate the IL-1 and IL-6-induced expression of acute phase proteins. Synergistic effects between GCs and IL-1 and IL-6 have also been observed in human $\mathrm{B}$ cells, potently inducing the production of IgG and IgM (Emilie et al, 1988). Other biological responses to a variety of cytokines such as IL-2 (Fernandez-Ruiz et al, 1989), Interferon (INF) $\gamma$ (Bergsteindottir et al, 1992) and granulocyte colony-stimulating factor (G-CSF) are also enhanced in the presence of GCs.

A few studies have even shown that GCs promote the production and release of several cytokines, such as IL-6 and TNF- $\alpha$ (Liao et al, 1995; Alcorn et al, 1992). Despite the proven ability of GCs to suppress proinflammatory cytokine expression, there are a large number of studies showing that the expression of many cytokine receptors are potently upregulated by GCs. To date, it has been shown that membranebound receptors for IL-1, IL-2, IL-4, IL-6, IFN- $\gamma$,
G-CSF, and TNF- $\alpha$ are induced by GCs on several cell types (Wiegers and Reul, 1998). Up-regulation of membrane-bound receptors and associated signal transduction components enhances the effects, whereas up-regulation of soluble receptors ("decoy receptors") can attenuate the effects of the respective cytokine; soluble receptor up-regulation by GCs has only been shown for IL-1 and TNF- $\alpha$ (Wilckens and De Rijk, 1997; De Rijk, 1994). Furthermore, the common signal transducer gp130 has been found to be augmented by GCs (Pietzko et al, 1993; Schooltink et al, 1992); this subunit is shared by several cytokine receptors such as the IL-6, IL-11, leukemia inhibitory factor (LIF) receptors. Thus, GCs are able to potentiate the action of several cytokines by increasing the expression of a single, common subunit. In studies on patients with sepsis/septic shock, the synthetic GC methylprednisolone elevated proinflammatory cytokine serum levels, and not only failed to have any beneficial effect, but even increased mortality rate in some patient groups (Bone et al, 1987).

Recent studies indicate yet another ability of physiological GC levels to be proinflammatory, namely by inducing synthesis of macrophage migration inhibitory factor (MIF) (Donnelly and Bucala, 1997; Leech et al, 1999; Bucala, 1996). MIF was one of the first cytokines to be identified and was named because of its ability to prevent the random migration of macrophages in culture (David, 1966). Research since then revealed a broad range of proinflammatory actions of MIF such as induction of macrophage 
TNF- $\alpha$ synthesis, up-regulation of phagocytosis, induction of nitric oxide synthase activity, and playing an important role as a cofactor in T-cell activation (Donnelly and Bucala, 1997; Juettner et al, 1998). Thus, amid the textbook picture of GCs being antiinflammatory in the periphery, there are numerous instances where they are anything but. Recent work suggests some instances of proinflammatory GC effects in the CNS as well.

A profound proinflammatory effect of GCs on the innate immune system, which also plays a major part in CNS inflammation, is the mobilization of the so called "bone marrow reserve" of granulocytes, which results in a pronounced peripheral neutrophilia (Goulding et al, 1998). Several studies even observed that stress-induced increases in GC concentrations enhanced the adaptive immune response by redistributing leukocytes to local areas of injury or infection (Dhabhar et al, 1996; Dhabhar and McEwen, 1996, 1997). Several investigators found a GC-induced selective suppression of cellular adaptive immunity ( $\mathrm{T}$ cells) and enhancing of humoral (B cells, antibodies) immunity (see Elenkov et al, 1999, for review).

In a recent study, dexamethasone treatment failed to down-regulate the cytokines IL- $1 \alpha$ and TNF- $\alpha$ after chemically induced hippocampal injury in mice (Bruccoleri et al, 1999). GCs are of no therapeutic benefits in stroke patients (Millikan et al, 1987); nonsteroidal anti-inflammatory drugs exert a stronger protective effect in Alzheimer's disease (Asanuma et al, 2001; Breitner, 1996), and several studies argue even against their use in the treatment of poststroke edema (Fishman, 1982; Tominaga et al, 1988). Furthermore, GC treatment failed to have beneficial effects in a recent clinical trial with Alzheimer's patients (Aisen et al, 2000) and was also not recommended for treatment of Guillain-Barré syndrome (Hughes, 2001), a disease involving inflammation of peripheral nerves. Administration of dexamethasone (Kiwerski, 1993; Hall and Braughler, 1982) and methylprednisolone (Bracken et al, 1990, 1997), however, have resulted in beneficial effects in cases of spinal cord trauma. However, because these data are now strongly criticized (Nesathurai, 1998) because of the study design and the inability of several other groups to reproduce the results, the observed beneficial GC effect remains at least questionable. Furthermore, a number of studies indicate that either GCs failed to have anti-inflammatory actions in the CNS under certain circumstances or their potentially beneficial anti-inflammatory effects were outweighed by their damaging effects on neurons. Even more surprisingly, some studies even demonstrated proinflammatory GC effects in the CNS: 5-lipoxygenase (5-LO), the enzyme crucial for the biosynthesis of inflammatory leukotrienes, is present in neurons and 5 -LO expression has been found to be increased in the rat brain after GC treatment (Uz et al, 1999) and during aging (Uz et al, 1998). Because aging is also associ- ated with increased GC levels, it is certainly interesting to look at the effects of aging on the immune system. Despite a general immunosenescence (decrease of immunological parameters such as phagocytosis, cell trafficking, etc.), some increased immune functions like IL-4, IL-6, and TNF- $\alpha$ production could be observed (Straub et al, 2000). All these examples clearly demonstrate that GCs not only suppress immune function but have also the potential to enhance certain parts of the immune system.

We could also confirm this in a recent study from our group (Dinkel and Sapolsky, 2003). In order to reconcile the anti-inflammatory and potentially beneficial GC effects with their ability to worsen the outcome after a neurological insult, we addressed the question how this acute inflammatory reaction is affected by different levels of GCs. We investigated the GC effect on lesion size, cellular inflammatory infiltrate, and mRNA cytokine pattern after excitotoxic brain injury in the rat hippocampus. Kainic acid was injected into the hippocampus of adrenalectomized/basal GC-supplemented, intact, and corticosterone pretreated rats. First, we could confirm that elevated GCs accelerated and exacerbated the kainate-induced neuronal damage. In all three groups, activated microglia as well as bloodborne granulocytes and macrophages were detected after kainate injection. Compared to basal GC levels, acute high GC levels reduced these inflammatory cells at early timepoints, but cell numbers were increased later on, suggesting a delaying and proinflammatory effect of GCs. Even more surprisingly, chronically elevated GC levels resulted in rapid infiltration and a further increase of cellular infiltrate compared to the other two groups. In contrast to their immunosuppressive effects in the periphery (reduction of cellular inflammatory infiltrate), GCs seemed to have a proinflammatory effect (increase of total inflammatory cell numbers) in this model of CNS inflammation. In the periphery, GCs reduce inflammatory infiltration by suppressing ICAM-1, an adhesion molecule expressed on endothelial cells, which is necessary for extravasation of granulocytes and macrophages from the bloodstream into the inflamed tissue (Cato and Wade, 1996; Perretti and Flower, 1994). In the context of a neurological insult, GCs could alter blood-brain barrier permeability to facilitate recruitment of blood-borne cells into the CNS. This would dramatically increase the number of infiltrating cells, considering reports that GCs delay apoptosis in neutrophils and cause peripheral neutrophilia (see Table 1; proinflammatory effects).

CNS cytokine expression is normally low (Vitkovic, 2000). As part of the inflammatory reaction in various neurological insults, an increased expression of proinflammatory cytokines (e.g. IL- $1 \alpha$, TNF- $\alpha$ ) has been detected (Dirnagl, 1999; Iadecola and Alexander, 2001; de Bock et al, 1996). We found elevated mRNA levels of the proinflammatory 
cytokines IL- $1 \alpha$, IL- $1 \beta$, IL-6, and TNF- $\alpha$ in all three groups after kainate injection. According to the timepoints of detection, these cytokine mRNAs seemed to have been produced by neurons and glial cells, thus providing a certain cytokine microenvironment that also affects the later infiltrating inflammatory cells. Consistent with known peripheral anti-inflammatory GC effects (Table 1), acute high GC levels inhibited IL- $1 \alpha$, IL- $1 \beta$, TNF- $\alpha$, but not IL-6, mRNA synthesis compared to basal GC levels. In contrast, chronically high GC levels caused an increase of all these four proinflammatory cytokine messages compared to basal GC levels, thus revealing yet another unexpected proinflammatory effect of GCs in CNS inflammation. Commensurate with this, GCs are of no particular benefits in stroke patients (Millikan et al, 1987) and their use to control poststroke edema is even associated with worsening the aspects of neurological outcome (Fishman, 1982; Tominaga et al, 1988). Our study showed that in the context of excitotoxic brain injury, GCs, depending on the dosage, may exert not only suppressive, but also permissive, and even strong enhancing effects on acute inflammation. These effects could further explain how GCs are worsening the outcome of neurological insults.

\section{Glucocorticoids and viral infections}

Given the number of neurotropic viruses (Table 2), it may be interesting to address the effect of GCs on the outcome of viral infection of the brain. A

Table 2 Neurotropic viruses (Peterson et al, 1997): the expression of cytokines during infection, physiological symptoms, and the presence or absence of a glucocorticoid response element (GRE) in the viral genome

\begin{tabular}{|c|c|c|c|c|c|}
\hline & \multicolumn{3}{|c|}{ Cytokines } & \multirow{2}{*}{$\begin{array}{l}\text { Physiological symptom(s) } \\
\text { and pathology }\end{array}$} & \multirow[b]{2}{*}{$G R E$} \\
\hline & $I L-1 \alpha / \beta$ & $I L-6$ & $T N F-\alpha$ & & \\
\hline \multicolumn{6}{|l|}{ Herpes viruses } \\
\hline $\begin{array}{l}\text { Herpes simplex virus I } \\
\text { (Neuronal) }\end{array}$ & $\begin{array}{r}\uparrow \beta(1) \\
\mathrm{CNS}\end{array}$ & $\uparrow(2)$ & $\uparrow(3)$ & $\begin{array}{l}\text { Encephalitis/persistent } \\
\text { latent infection }\end{array}$ & $+(4)$ \\
\hline Cytomegalovirus & $\uparrow \alpha(5)$ & $\uparrow(5)$ & $\uparrow(5)$ & Encephalitis & $\pm(6)^{\mathrm{C}}$ \\
\hline Epstein-Barr Virus & $\uparrow \alpha / \beta(7)$ & $\uparrow(8)$ & $\uparrow(8)$ & Encephalitis & $+(9)$ \\
\hline Human herpesvirus 6 & $0 \beta(10)$ & - & - & Encephalitis/encephalopathy & $\pm^{\mathrm{d}}$ \\
\hline B virus $^{\mathrm{a}}$ & - & - & - & Encephalitis & $\pm^{\mathrm{d}}$ \\
\hline \multicolumn{6}{|l|}{ Enteroviruses } \\
\hline Polioviruses (Neuronal) & $\uparrow(11)$ & $\downarrow(12)^{\mathrm{e}}$ & $\downarrow(14) \uparrow(11)^{\mathrm{f}}$ & Poliomyelitis/paralysis & - \\
\hline Coxsackieviruses & $\uparrow(11)$ & $\uparrow(13)$ & $\uparrow(11)$ & Myocarditis/meningitis & - \\
\hline Echoviruses & $\begin{array}{l}\uparrow \beta(15) \\
\text { CNS }\end{array}$ & - & $\begin{array}{l}\uparrow(15) \\
\text { CNS }\end{array}$ & Meningitis & - \\
\hline \multicolumn{6}{|l|}{ Retroviruses } \\
\hline HIV & $\begin{array}{c}\uparrow \beta(16) \\
\mathrm{CNS}\end{array}$ & $\begin{array}{l}\uparrow(17,18) \\
\mathrm{CNS}\end{array}$ & $\begin{array}{l}\uparrow(16,19) \\
\text { CNS }\end{array}$ & Dementia & $+(20)$ \\
\hline $\begin{array}{l}\text { Human T lymphotrophic } \\
\text { virus type I }\end{array}$ & $\uparrow \alpha(21)$ & $\uparrow(22)$ & $\begin{array}{l}\uparrow(23) \\
\text { CNS }\end{array}$ & Chronic demyelination & - \\
\hline Rabies virus (Neuronal) & $\begin{array}{l}\uparrow \beta(24) \\
\mathrm{CNS}\end{array}$ & $\begin{array}{l}\uparrow(24,25) \\
\text { CNS }\end{array}$ & $\begin{array}{l}\uparrow(25) \\
\text { CNS }\end{array}$ & Encephalopathy & - \\
\hline Mumps virus & $\begin{array}{l}\uparrow \beta(26,27) \\
\text { CNS }\end{array}$ & $\begin{array}{l}\uparrow(28) \\
\text { CNS }\end{array}$ & $\begin{array}{l}\uparrow(27), 0(26) \\
\text { CNS }\end{array}$ & Encephalitis & - \\
\hline $\begin{array}{l}\text { Lymphocytic choriomeningitis } \\
\text { virus }\end{array}$ & $\begin{array}{l}\uparrow(29) \\
\text { CNS }\end{array}$ & - & $\uparrow(30)$ & Meningitis & - \\
\hline Measles virus & $\uparrow(27,31,32,33)$ & $\uparrow(32,33)$ & $\uparrow(31,32,33)$ & Encephalitis, SSPE ${ }^{b}$ & - \\
\hline Rubella virus & - & $\uparrow(27)$ & - & Encephalitis & - \\
\hline JC virus & - & - & - & Demyelination & - \\
\hline Borna disease virus (Neuronal) & $\begin{array}{l}0 \beta(34) \\
\text { CNS }\end{array}$ & - & $\begin{array}{l}0 \text { (34) } \\
\text { CNS }\end{array}$ & Behavioral abnormalities & - \\
\hline
\end{tabular}

${ }^{\mathrm{a}}$ Cercopithecine herpesvirus (B virus).

bSubacute sclerosing panencephalitis.

'Reactivation in the presence of glucocorticoid.

${ }^{\mathrm{d}}$ Presence of GRE unknown but probable.

eIL-6 secretion inhibited in infected cells.

${ }^{\mathrm{f}} \mathrm{TNF}$ receptor transport to cell membrane inhibited in infected cells.

Arrows indicate an increase or decrease in cytokine level, CNS indicates that expression of a particular cytokine was determined within and during infection of the central nervous system. (Neuronal) indicates primary site of infection and/or primary ecological niche of the respective virus versus opportunistic infection of the brain parenchyma.

References by first authors: (1) Ben-Hur, 2001. (2) Noisakran, 1998. (3) Gosselin, 1992. (4) Hardwicke, 1997. (5) Ruzek, 1997. (6) Tanaka, 1984. (7) Foss, 1994. (8) Andersson, 1996. (9) Kupfer, 1990. (10) Inagi, 1996. (11) Vreugdenhil, 2000. (12) Dodd, 2001. (13) Heim, 2000. (14) Neznanov, 2001. (15) Nishikawa, 2000. (16) Ilyin, 1997. (17) Koedel, 1999. (18) Zidovetzki, 1998. (19) Nuovo, 1996. (20) Ghosh, 1992. (21) Mori, 1996. (22) Yamamura, 1998. (23) Fox, 1996. (24) Marquette, 1996. (25) Camelo, 2000. (26) Takikita, 2001. (27) Cavallo, 1992. (28) Joblonowska, 1999. (29) Hildeman, 2000. (30) Nguyen, 1999. (31) Leopardi, 1992. (32) Yamabe, 1994. (33) Schneider-Schaulies, 1993. (34) Sauder, 2001. 
number of studies (for a detailed review, see Pearce et al, 2001) have shown an up-regulation of proinflammatory cytokines (Table 2) and in turn cytokinemediated increased GC release during viral infections. The available data examining the stimulation of the HPA axis by cytokines indicate that depending on the virus and the respective cytokine pattern, several immune-endocrine pathways can be invoked. Endogenous GCs are capable of modulating the immune response by supporting protective immunity as well as suppressing detrimental effects of antiviral immunity such as septic shock. In mice, adrenalectomy before infection with cytomegalovirus (CMV) results in lethality but GC replacement prevents virus-induced lethality (Ruzek et al, 1999). In humans, chronically elevated GC levels, caused by chronic stress situations, are associated with enhanced susceptibility to viral infection (Glaser and Kiecolt-Glaser, 1998).

Because several viral genomes contain GREs (Table 2), GCs might also influence early phases of viral infection by stimulating viral replication via these GREs. Recent findings even indicate that human immunodeficiency virus (HIV)-1-associated protein $\mathrm{Vpr}$ is able to act as transcriptional activator and contains a nuclear receptor-binding motif that binds directly to GR (Kino and Chrousos, 2001). Therefore, Vpr may stimulate viral proliferation (facilitation of viral gene transcription) and suppress the host immune system by inducing GC hypersensitivity (GR binding).

In a recently developed animal model for herpes encephalitis, it was found that treating the animals with dexamethasone decreased viral load. But in the presence of acyclovir, a small, nonsignificant increase in viral load was observed, and acyclovir in combination with dexamethasone did not decrease viral spread over acyclovir by itself (Thompson et al, 2000). The role of circulating GCs in the pathogenesis of HSV-1 encephalitis was also examined. Circulating GCs were removed or blocked by adrenalectomy, hypophysectomy, or receptor blocking. In the absence of circulating GCs, fever and behavioral changes (motor hyperactivity and agression) associated with herpes encephalitis were not observed, although overall mortality was unchanged. With GC replacement therapy, the clinical responses to HSV-1 encephalitis was again observed. IL-10 levels were also measured and shown to increase with infection only in the presence of GCs (Ben-Hur et al, 2001). Overall, in the case of HSV-1, the use of GCs to abrogate the course of infection is unclear. Dexamethasone administration resulted in a worsened neurpathological outcome in a model human HIV-1 encephalitis in SCID mice (Limoges et al, 1997). In another study, pneumovirusinfected mice responded to hydrocortisone treatment with enhanced viral replication and accelerated mortality (Domachowske et al, 2001). These results indicate that exogenous administration of GCs may be of limited benefit or even be harmful for treatment of certain viral infections.

\section{Conclusion}

The major finding reported in this review is that GCs are not always anti-inflammatory and can even be proinflammatory in peripheral as well as in CNS inflammation. Although there are not enough studies yet to begin to delineate rules that explain why and under what circumstances GCs have anti- or proinflammatory effects, based on small numbers of data, there is, however, at least room to speculate as to what parameters determine the respective GC effects.

\section{Synthetic versus endogenous GCs}

Much of the current understanding of the mechanisms of GC action stems from observations made with synthetic/exogenous GCs and their effect on peripheral immune activation. These pharmacological agents, such as prednisolone or dexamethasone, have been proven to be several times more potent immunosuppressants than endogenous GCs, such as the primate cortisol and the rodent corticosterone (Nelson, 1995; Wilckens and De Rijk, 1997; Craig and Stitzel, 1994); in addition, therapeutic doses are usually much higher than physiological levels of GCs. The physiological role of GCs in relation to immune reactions on the basis of in vitro as well as in vivo data cannot be solely based on the use of synthetic ligands without comparison with the endogenous GCs; this is especially the case because synthetic GCs are exclusively GR agonists and do not bind to MRs. For example, GCs are bound in the hippocampus by the high-affinity MR, which is almost entirely occupied under basal conditions. In contrast, the hippocampus also contains the low-affinity GR, which is not heavily occupied until stress levels of GCs are achieved. Therefore, it is certainly questionable whether the actions of endogenous GCs on inflammation could be predicted from those observations.

\section{Microenvironment and type of injury}

Furthermore, considering the extraordinary microenvironment of the CNS, one should also be very cautious in assuming that GC effects seen in peripheral inflammation also apply to CNS inflammation. Our study (Dinkel and Sapolsky, 2001), for example, investigated effects of GCs on the innate immune system and neurons/glial cells in the context of acute CNS inflammation. GCs might down-regulate cytokine production of certain immune cells, but just cause the opposite effect in neurons or glial cells. The effects of GCs are determined by highly specific regulatory mechanisms, which may also display tissue specificity. Given the growing appreciation of the complexity and heterogeneity of various forms of brain injury, GC use as treatment may find a rational place in management only of a subset of neurological insults. 


\section{Chronic versus acute exposure}

Another important factor to consider is whether GCs are elevated acutely or chronically. Chronic exposure to GCs might induce changes on certain cell types (e.g., receptor up- or downregulation) that result in completely different cellular responses to tissue injury and inflammatory mediators.

There is convincing evidence for the effectiveness of GCs in the acute phase of optic neuritis and multiple sclerosis attacks (Brusaferri and Candelise, 2000), but there is no beneficial GC effect on the progression of the disabilities. The initial effects of highdose therapy occur rapidly, but are lost as the diseases progress. This declining responsiveness to GCs over time and the known side-effects limit the therapeutic use of GCs in multiple sclerosis and other autoimmune diseases. Furthermore, there is no consensus about the optimal form, dose, route, or duration of corticosteroid therapy (Noseworthy et al, 2000).

Myasthenia gravis patients who do not respond well to anticholinesterase treatment are candidates for GC (prednisolone) therapy. Interestingly, there is a well-documented early exacerbartion of myasthenic weakness immediately after starting high-dose GC administration (Pascuzzi et al, 1984). In an attempt to avoid this transient exacerbation, treatment is started at a low dose, then gradually increased, and eventually (on remission) reduced (Vincent et al, 2001).

\section{References}

Adamson DC, Wildemann B, Sasaki M, Glass JD, McArthur JC, Christov VI, Dawson TM, Dawson VL (1996). Immunologic NO synthase: elevation in severe AIDS dementia and induction by HIV-1 gp41. Science 274: 19171921.

Aisen PS, Davis KL, Berg JD, Schafer K, Campbell K, Thomas RG, Weiner MF, Farlow MR, Sano M, Grundman M, Thal LJ (2000). A randomized controlled trial of prednisone in Alzheimer's disease. Alzheimer's Disease Cooperative Study. Neurology 54: 588-593.

Akassoglou K, Probert L, Kontogeorgos G, Kollias G (1997). Astrocyte-specific but not neuron-specific transmembrane TNF triggers inflammation and degeneration in the central nervous system of transgenic mice. $J$ Immunol 158: 438-445.

Akiyama H, Tooyama I, Kondo H, Ikeda K, Kimura H, McGeer EG, McGeer PL (1994). Early response of brain resident microglia to kainic acid-induced hippocampal lesions. Brain Res 635: 257-268.

Alcorn JM, Fierer J, Chojkier M (1992). The acute-phase response protects mice from D-galactosamine sensitization to endotoxin and tumor necrosis factor-alpha. Hepatology 15: 122-129.

Andersson J (1996). Clinical and immunological considerations in Epstein-Barr virus-associated diseases. Scand J Infect Dis 100: 72-82.

Asanuma M, Nishibayashi-Asanuma S, Miyazaki I, Kohno M, Ogawa N (2001). Neuroprotective effects of non-

\section{Clinical implications}

Although high-dose GC therapy has become the standard for acute management of certain forms of spinal cord injury, its therapeutic value in traumatic brain injury has been severely questioned (Segatore, 1999). In two major studies (Lefering and Neugebauer, 1995; Cronin et al, 1995) reviewing available randomized control trials, it has been recommended that high-dose GC treatment of septic shock patients with severe infection should be abandoned. On the other hand, GCs remain the most effective therapy for inflammatory disorders such as asthma or rheumatoid arthritis (van der Velden, 1998; Belvisi et al, 2001). More clinical investigations are needed in order to understand the molecular and cellular mechanisms responsible for the inefficacy of GCs in the treatment of disorders such as septic shock or inflammation after stroke.

When studying GCs and inflammation, one has to take into consideration that effects will differ depending on GC type (e.g., synthetic, endogenous), GC concentrations, location (CNS, periphery), type of inflammation (innate, adaptive, combined), and immune cells (e.g., T cells, B cells, granulocytes) involved. In light of these complex multifactoral interactions and the increasing number of studies showing proinflammatory GC effects, it seems appropriate to reconsider the dogma of GCs being universally immunosuppressive and, accordingly, the broad use of GCs as the anti-inflammatory drug of choice in a very large number of CNS disorders.

steroidal anti-inflammatory drugs by direct scavenging of nitric oxide radicals. J Neurochem 76: 1895-1904.

Badie B, Schartner JM, Paul J, Bartley BA, Vorpahl J, Preston JK (2000). Dexamethasone-induced abolition of the inflammatory response in an experimental glioma model: a flow cytometry study. J Neurosurg 93: 634639.

Bailey JM, Makheja AN, Pash J, Verma M (1988). Corticosteroids suppress cyclooxygenase messenger RNA levels and prostanoid synthesis in cultured vascular cells. Biochem Biophys Res Commun 157: 11591163.

Banati RB, Gehrmann J, Schubert P, Kreutzberg GW (1993). Cytotoxicity of microglia. Glia 7: 111-118.

Barber AE, Coyle SM, Marano MA, Fischer E, Calvano SE, Fong Y, Moldawer LL, Lowry SF (1993). Glucocorticoid therapy alters hormonal and cytokine responses to endotoxin in man. J Immunol 150: 1999-2006.

Barnes PJ, Adcock I (1993). Anti-inflammatory actions of steroids: molecular mechanisms. Trends Pharmacol Sci 14: $436-441$.

Barone FC, Feuerstein GZ (1999). Inflammatory mediators and stroke: new opportunities for novel therapeutics. J Cereb Blood Flow Metab 19: 819-834.

Bauer ME, Vedhara K, Perks P, Wilcock GK, Lightman SL, Shanks N (2000). Chronic stress in caregivers of dementia patients is associated with reduced lymphocyte sensitivity to glucocorticoids. J Neuroimmunol 103: 84-92. 
Baumann H, Gauldie J (1995). The acute phase response. Immunol Today 15: 74-80.

Beal MF (1992). Mechanisms of excitotoxicity in neurologic diseases. FASEB J 6: 3338-3344.

Beal MF (1995). Aging, energy, and oxidative stress in neurodegenerative diseases. Ann Neurol 38: 357-366.

Beamer NB, Coull BM, Clark WM, Briley DP, Wynn M, Sexton G (1998). Persistent inflammatory response in stroke survivors. Neurology 50: 1722-1728.

Becher B, Barker PA, Owens T, Antel JP (1998). CD95CD95L: can the brain learn from the immune system? Trends Neurosci 21: 114-117.

Becker KJ (1998). Inflammation and acute stroke. Curr Opin Neurol 11: 45-49.

Becker KJ (2001). Targeting the central nervous system inflammatory response in ischemic stroke. Curr Opin Neurol 14: 349-353.

Belvisi MG, Brown TJ, Wicks S, Foster ML (2001). New glucocorticosteroids with an improved therapeutic ratio? Pulm Pharmacol Ther 14: 221-227.

Ben-Hur T, Cialic R, Itzik A, Barak O, Yirmiya R, Weidenfeld J (2001). A novel permissive role for glucocorticoids in induction of febrile and behavioral signs of experimental herpes simplex virus encephalitis. Neurosci 108: 119-127.

Bergsteindottir K, Brennan A, Jessen KR, Mirsky R (1992). In the presence of dexamethasone, gamma interferon induces rat oligodendrocytes to express major histocompatibility complex class II molecules. Proc Natl Acad Sci USA 89: 9054-9058.

Berkenbosch F, van Oers J, del Rey A, Tilders F, Besedovsky $\mathrm{H}$ (1987). Corticotropin-releasing factor-producing neurons in the rat activated by interleukin-1. Science 238: 524-526.

Besedovsky H, del Rey A, Sorkin E, Dinarello CA (1986). Immunoregulatory feedback between interleukin-1 and glucocorticoid hormones. Science 233: 652-654.

Bhargava A, Meijer OC, Dallman MF, Pearce D (2000). Plasma membrane calcium pump isoform 1 gene expression is repressed by corticosterone and stress in rat hippocampus. J Neurosci 20: 3129-3138.

Birnstiel S, List TJ, Beck SG (1995). Chronic corticosterone treatment maintains synaptic activity of CA1 hippocampal pyramidal cells: acute high corticosterone administration increases action potential number. Synapse 20: 117-124.

Bone RC, Fisher CJ Jr, Clemmer TP, Slotman GJ, Metz CA, Balk RA (1987). A controlled clinical trial of high-dose methylprednisolone in the treatment of severe sepsis and septic shock. N Engl J Med 317: 653-658.

Boumpas DT, Chrousos GP, Wilder RL, Cupps TR, Balow JE (1993). Glucocorticoid therapy for immune-mediated diseases: basic and clinical correlates. Ann Intern Med 119: $1198-1208$.

Bracken MB, Shepard MJ, Collins WF, Holford TR, Young W, Baskin DS, Eisenberg HM, Flamm E, Leo-Summers L, Maroon J, et al (1990). A randomized, controlled trial of methylprednisolone or naloxone in the treatment of acute spinal-cord injury. Results of the Second National Acute Spinal Cord Injury Study. NEngl J Med 322: 14051411.

Bracken MB, Shepard MJ, Holford TR, Leo-Summers L, Aldrich EF, Fazl M, Fehlings M, Herr DL, Hitchon PW, Marshall LF, Nockels RP, Pascale V, Perot PL Jr, Piepmeier J, Sonntag VK, Wagner F, Wilberger JE, Winn HR, Young W (1997). Administration of methylpred- nisolone for 24 or 48 hours or tirilazad mesylate for 48 hours in the treatment of acute spinal cord injury. Results of the Third National Acute Spinal Cord Injury Randomized Controlled Trial. National Acute Spinal Cord Injury Study. JAMA 277: 1597-1604.

Breitner JC (1996). The role of anti-inflammatory drugs in the prevention and treatment of Alzheimer's disease. Annu Rev Med 47: 401-411.

Bruccoleri A, Pennypacker KR, Harry GJ (1999). Effect of dexamethasone on elevated cytokine mRNA levels in chemical-induced hippocampal injury. J Neurosci Res 57: 916-926.

Bruce AJ, Boling W, Kindy MS, Peschon J, Kraemer PJ, Carpenter MK, Holtsberg FW, Mattson MP (1996). Altered neuronal and microglial responses to excitotoxic and ischemic brain injury in mice lacking TNF receptors. Nat Med 2: 788-794.

Brusaferri F, Candelise L (2000). Steroids for multiple sclerosis and optic neuritis: a meta-analysis of randomized controlled clinical trials. J Neurol 247: 435-442.

Bucala R (1996). MIF rediscovered: cytokine, pituitary hormone, and glucocorticoid-induced regulator of the immune response. FASEB J 10: 1607-1613.

Burchard K (2001). A review of the adrenal cortex and severe inflammation: quest of the "eucorticoid" state. J Trauma 51: 800-814.

Burton JL, Kehril ME Jr, Kapsil S, Horst RL (1995). Regulation of L-selectin and CD18 on bovine neutrophils by glucocorticoids: effects of cortisol and dexamethasone. J Leukoc Biol 57: 317-325.

Calandra T, Bernhagen J, Metz CN, Spiegel LA, Bacher M, Donnelly T, Cerami A, Bucala R (1995). MIF as a glucocorticoid-induced modulator of cytokine production. Nature 377: 68-71.

Camelo S, Lafage M, Lafon M (2000). Absence of the p55 $\mathrm{Kd} \mathrm{TNF}$-alpha receptor promotes survival in rabies virus acute encephalitis. J Neurovirol 6: 507-518.

Campbell IL, Abraham CR, Masliah E, Kemper P, Inglis JD, Oldstone MB, Mucke L (1993). Neurologic disease induced in transgenic mice by cerebral overexpression of interleukin 6. Proc Natl Acad Sci USA 90: 1006110065.

Calogero AE, Sternberg EM, Bagdy G, Smith C, Bernardini R, Aksentijevich S, Wilder RL, Gold PW, Chrousos GP (1992). Neurotransmitter-induced hypothalamicpituitary-adrenal axis responsiveness is defective in inflammatory disease-susceptible Lewis rats: in vivo and in vitro studies suggesting globally defective hypothalamic secretion of corticotropin-releasing hormone. Neuroendocrinology 55: 600-608.

Cato AC, Wade E (1996). Molecular mechanisms of antiinflammatory action of glucocorticoids. BioEssays 18: 371-378.

Cavallo MG, Baroni Mg, Toto A, Gearing AJ, Forsey T, Andreani D, Thorpe R, Pozzilli P (1992). Viral infections induces cytokine release by beta islet cells. Immunology 75: $664-668$.

Chapman GA, Moores K, Harrison D, Campbell CA, Stewart BR, Strijbos PJ (2000). Fractalkine cleavage from neuronal membranes represents an acute event in the inflammatory response to excitotoxic brain damage. J Neurosci 20: RC87.

Cheng B, Christakos S, Mattson MP (1994). Tumor necrosis factors protect neurons against metabolic-excitotoxic insults and promote maintenance of calcium homeostasis. Neuron 12: 139-153. 
Chrousos GP (1995). The hypothalamic-pituitary-adrenal axis and immune mediated inflammation. $N$ Engl J Med 332: 1351-1362.

Colton C, Wilt S, Gilbert D, Chernyshev O, Snell J, Dubois-Dalcq M (1996). Species differences in the generation of reactive oxygen species by microglia. Mol Chem Neuropathol 28: 15-20.

Cox G, Austin RC (1997). Dexamethasone-induced suppression of apoptosis in human neutrophils requires continuous stimulation of new protein synthesis. J Leukoc Biol 61: 224-230.

Coyle PK (1999). Glucocorticoids in central nervous system bacterial infection. Arch Neurol 56: 796-801.

Craig CR, Stitzel RE (1994). Modern pharmacology, 4th ed. Boston: Little, Brown, p 737.

Cronin L, Cook DJ, Carlet J, Heyland DK, King D, Lansang MA, Fisher CJ Jr (1998). Corticosteroid treatment for sepsis: a critical appraisal and meta-analysis of the literature. Crit Care Med 23: 1430-1439.

Cronstein BN, Kimmel SC, Levin RI, Martiniuk F, Weissmann G (1992). A mechanism for the antiinflammatory effects of corticosteroids: the glucocorticoid receptor regulates leukocyte adhesion to endothelial cells and expression of endothelial-leukocyte adhesion molecule 1 and intercellular adhesion molecule 1. Proc Natl Acad Sci USA 89: 9991-9995.

Dalakas MC (1995). Basic aspects of neuroimmunology as they relate to immunotherapeutic targets: present and future prospects. Ann Neurol 37 (Suppl 1): S2-S13.

David JR (1966). Delayed hypersensitivity in vitro: its mediation by cell-free substances formed by lymphoid cellantigen interaction. Proc Natl Acad Sci USA 56: 72-77.

Davis JM, Albert JD, Tracy KJ, Calvano SE, Lowry SF, Shires GT, Yurt RW (1991). Increased neutrophil mobilization and decreased chemotaxis during cortisol and epinephrine infusions. J Trauma 31: 725-731; discussion 731-732.

de Bock F, Dornand J, Rondouin G (1996). Release of TNF alpha in the rat hippocampus following epileptic seizures and excitotoxic neuronal damage. Neuroreport 7: 11251129.

De Bosscher K, Vanden Berghe W, Haegeman G (2000). Mechanisms of antiinflammatory action and of immunosuppression by glucocorticoids: negative interference of activated glucocorticoid receptor with transcription factors. J Neuroimmunol 109: 16-22.

De Kloet ER, Vreugdenhil E, Oitzl MS, Joels M (1998). Brain corticosteroid receptor balance in health and disease. Endocr Rev 19: 269-301.

DeGraba TJ (1998). The role of inflammation after acute stroke: utility of pursuing anti-adhesion molecule therapy. Neurology 51 (Suppl 3): S62-S68.

DeGraba TJ, Pettigrew LC (2000). Why do neuroprotective drugs work in animals but not humans? Neurol Clin 18: 475-493.

De Keyser J, Sulter G, Luiten PG (1999). Clinical trials with neuroprotective drugs in acute ischaemic stroke: are we doing the right thing? Trends Neurosci 22: 535-540.

DeRijk R, Michelson D, Karp B, et al (1997). Exercise and circadian rhythm-induced variations in plasma cortisol differentially regulate interleukin-1 beta (IL-1 beta), IL-6, and tumor necrosis factor-alpha (TNF alpha) production in humans: high sensitivity of TNF alpha and resistance of IL-6. J Clin Endocrinol Metab 82: 2182-2191.

del Zoppo GJ, Becker KJ, Hallenbeck JM (2001). Inflammation after stroke: is it harmful? Arch Neurol 58: 669-672.
Dermietzel R (1975). Junctions in the central nervous system of the cat. IV. Interendothelial junctions of cerebral blood vessels from selected areas of the brain. Cell Tissue Res 164: 45-62.

Dhabhar FS, Miller AH, McEwen BS, Spencer RL (1996). Stress-induced changes in blood leukocyte distribution. Role of adrenal steroid hormones. JImmunol 157: 16381644.

Dhabhar FS, McEwen BS (1996). Stress-induced enhancement of antigen-specific cell-mediated immunity. $J$ Immunol 156: 2608-2615.

Dhabhar FS, McEwen BS (1997). Acute stress enhances while chronic stress suppresses cell-mediated immunity in vivo: a potential role for leukocyte trafficking. Brain Behav Immun 11: 286-306.

Dinkel K, Sapolsky RM (2003). Novel glucocorticoid effects on acute inflammation in the central nervous system. $J$ Neurochem In press.

Dirnagl U, Iadecola C, Moskowitz MA (1999). Pathobiology of ischaemic stroke: an integrated view. Trends Neurosci 22: 391-397.

Dodd DA, Giddings TH Jr, Kirkegaard K (2001). Poliovirus 3A protein limits interleukin-6 (IL-6), IL-8, and beta interferon secretion during viral infection. $J$ Virol 75: 8158-8165.

Domachowske JB, Bonville CA, Ali-Ahmad D, Dyer KD, Easton AJ, Rosenberg HF (2001). Glucocorticoid administration accelerates mortality of pneumovirus-infected mice. J Infect Dis 184: 1518-1523.

Donnelly SC, Bucala R (1997). Macrophage migration inhibitory factor: a regulator of glucocorticoid activity with a critical role in inflammatory disease. Mol Med Today Nov: 502-507.

Elenkov IJ, Webster EL, Torpy DJ, Chrousos GP (1999). Stress, corticotropin-releasing hormone, glucocorticoids, and the immune/inflammatory response: acute and chronic effects. Ann N Y Acad Sci 876: 1-11; discussion 11-13.

Emilie D, Crevon MC, Auffredou MT, Galanaud P (1988). Glucocorticosteroid-dependent synergy between interleukin 1 and interleukin 6 for human B lymphocyte differentiation. Eur J Immunol 18: 2043-2047.

Ferguson TA, Griffith TS (1997). A vision of cell death: insights into immune privilege. Immunol Rev 156: 167184.

Fernandez-Ruiz E, Rebollo A, Nieto MA, Sanz E, Somoza C, Ramirez F, Lopez-Rivas A, Silva A (1989). IL-2 protects T cell hybrids from the cytolytic effect of glucocorticoids. Synergistic effect of IL-2 and dexamethasone in the induction of high-affinity IL-2 receptors. J Immunol 143: 4146-4151.

Feuerstein GZ, Wang X (2001). Inflammation and stroke: benefits without harm? Arch Neurol 58: 672674.

Feuerstein GZ, Wang X, Barone FC (1998). In: Cerebrovascular disease: pathophysiology, diagnosis and management. Ginsberg M, Bogousslavsky J (eds.). Blackwell Science: Oxford, UK, pp 507-531.

Flippini G, Brusaferri F, Sibley WA, Citterio A, Ciucci G, Midgard R, Candelise L (2000). Corticosteroids or ACTH for acute exacerbations in multiple sclerosis. Cochrane Database Syst Rev 4.

Fishman RA (1982). Steroids in the treatment of brain edema. $N$ Engl J Med 306: 359-360.

Foss HD, Herbst H, Hummel M, Araujo I, Latza U, Rancso C, Dallenbach F, Stein H (1994). Patterns of cytokine gene 
expression in infectious mononucleosis. Blood 84: 707712.

Fox RJ, Levin MC, Jacobson S (1996). Tumor necrosis factor alpha expression in the spinal cord of human T-cell lymphotrophic virus type I associated myelopathy/ tropical spastic paraparesis patients. J Neurovirol 2: 297-298.

Galicich J, French L, Melly J (1961). Use of dexamethasone in treatment of cerebral edema associated with brain tumor. J Lancet 81: 46.

Gary DS, Bruce-Keller AJ, Kindy MS, Mattson MP (1998). Ischemic and excitotoxic brain injury is enhanced in mice lacking the p55 tumor necrosis factor receptor. J Cereb Blood Flow Metab 18: 1283-1287.

Getting SJ, Flower RJ, Perretti M (1997). Inhibition of neutrophil and monocyte recruitment by endogenous and exogenous lipocortin 1. Br J Pharmacol 120: 10751082.

Ghosh D (1992). Glucocorticoid receptor binding site in the HIV long terminal repeat. J Virol 66: 586-590.

Glaser R, Kiecolt-Glaser JK (1998). Stress-associated immune modulation: relevance to viral infections and chronic fatigue syndrome (review). Am J Med 105: 35S$42 \mathrm{~S}$.

Gosselin J, Flamand L, D’Addario M, Hiscott J, Menezes J (1992). Infection of peripheral blood mononuclear cells by herpes simplex and Epstien-Barr viruses. Differential induction of interleukin 6 and tumor necrosis factoralpha. J Clin Invest 89: 1849-1856.

Gould E, McEwen B, Tanapat P, Galea L, Fuchs E (1997). Neurogenesis in the dentate gyrus of the adult tree shrew is regulated by psychosocial stress and NMDA receptor activation. J Neurosci 18: 2492.

Gould E, Tanapat P, McEwen B, Flugge G, Fuchs E (1998). Proliferation of granule cell precursors in the dentate gyrus of adult monkeys is diminished by stress. Proc Natl Acad Sci USA 95: 3168.

Goulding NJ, Euzger HS, Butt SK, Perretti M (1998). Novel pathways for glucocorticoid effects on neutrophils in chronic inflammation. Inflamm Res 47(Suppl 3): S158S165.

Griffin DE, Wesselingh SL, McArthur JC (1994). Elevated central nervous system prostaglandins in human immunodeficiency virus-associated dementia. Ann Neurol 35: 592-597.

Hall ED, Braughler JM (1982). Glucocorticoid mechanisms in acute spinal cord injury: a review and therapeutic rationale. Surg Neurol 18: 320-327.

Hardwicke MA, Schaffer PA (1997). Differential effects of nerve growth factor and dexamethasone on herpes simplex virus type 1 oriL and oriS dependent DNA replication in PC12 cell. J Virol 71: 3580-3587.

Heim A, Zeuke S, Weiss S, Ruschewski W, Grumbach IM (2000). Transient induction of cytokine production in human myocardial fibroblasts by coxsackievirus B3. Circ Res 86: 753-759.

Hench P, Kendall EC, Slocumb CH, Polley HF (1949). The effects of a hormone of the adrenal cortex and of pituitary adrenocorticotropic hormone on rheumatoid arthritis. Proc Mayo Clin 24: 181-197.

Hetier E, Ayala J, Bousseau A, Prochiantz A (1991). Modulation of interleukin-1 and tumor necrosis factor expression by beta-adrenergic agonists in mouse ameboid microglial cells. Exp Brain Res 86: 407-413.

Hildeman D, Muller D (2000). Immunopathologic weight loss in intracranial LCMV infection initiated by the anorexigenic effects of IL-1 beta. Viral Immunol 13: 273285.

Hughes RA, van Der Meche FG (2000). Corticosteroids for treating Guillain-Barre syndrome. Cochrane Database Syst Rev 3.

Iadecola C (1997). Bright and dark sides of nitric oxide in ischemic brain injury. Trends Neurosci 20: 132-139.

Iadecola C, Alexander M (2001). Cerebral ischemia and inflammation. Curr Opin Neurol 14: 89-94.

Ilyin SE, Plata-Salaman CR (1997). HIV-1 envelope glycoprotein 120 regulates brain IL-1 beta system and TNFalpha mRNAs in vivo. Brain Res Bull 44: 67-73.

Inagi R, Guntapong R, Nakao M, Ishino Y, Kawanishi K, Isegawa Y, Yamanishi K (1996). Human herpesvirus 6 induces IL-8 gene expression in human hepatoma cell line, Hep G2. J Med Virol 49: 34-40.

Jacobson L, Sapolsky R (1991). The role of the hippocampus in feedback regulation of the hypothalamic-pituitaryadrenocortical axis. Endocr Rev 12: 118-134.

Joblonowska E, Lisiewicz J, Kuydowicz J, Pojda Z (1999). Levels of interleukin-6 in cerebrospinal fluid of patients with meningitis. Neurol Neurochir Polska 32: 161-165.

Joels M (2001). Corticosteroid actions in the hippocampus. J Neuroendocrinol 13: 657-669.

Joels M, de Kloet E (1989). Effects of glucocorticoids and norepinephrine on the excitability in the hippocampus. Science 245: 1502-1505.

Juttner S, Bernhagen J, Metz CN, Rollinghoff M, Bucala R, Gessner A (1998). Migration inhibitory factor induces killing of Leishmania major by macrophages: dependence on reactive nitrogen intermediates and endogenous TNF-alpha. J Immunol 161: 2383-2390.

Kellendonk C, Tronche F, Reichardt HM, Schutz G (1999). Mutagenesis of the glucocorticoid receptor in mice. J Steroid Biochem Mol Biol 69: 253-259.

Kern JA, Lamb RJ, Reed JC, Daniele RP, Nowell PC (1988). Dexamethasone inhibition of interleukin 1 beta production by human monocytes. Posttranscriptional mechanisms. J Clin Invest 81: 237-244.

Kerr D, Campbell L, Hao S, Landfield P (1989). Corticosteroid modulation of hippocampal potentials: increased effect with aging. Science 245: 1505-1509.

Kerschensteiner M, Gallmeier E, Behrens L, Leal VV, Misgeld T, Klinkert WE, Kolbeck R, Hoppe E, Oropeza-Wekerle RL, Bartke I, Stadelmann C, Lassmann H, Wekerle H, Hohlfeld R (1999). Activated human T cells, B cells, and monocytes produce brain-derived neurotrophic factor in vitro and in inflammatory brain lesions: a neuroprotective role of inflammation? J Exp Med 189: $865-870$.

Kino T, Chrousos GP (2001). Glucocorticoid and mineralocorticoid resistance/hypersensitivity syndromes. J Endocrinol 169: 437-445.

Kiwerski JE (1993). Application of dexamethasone in the treatment of acute spinal cord injury. Injury 24: 457460.

Koedel U, Kohleisen B, Sporer B, Lahrtz F, Ovod V, Fontana A, Erfle V, Pfister HW (1999). HIV type 1 Nef protein is a viral factor for leukocyte recruitment into the central nervous system. J Immunol 163: 1237-1245.

Koide T, Wieloch TW, Siesjo BK (1986). Chronic dexamethasone pretreatment aggravates ischemic neuronal necrosis. J Cereb Blood Flow Metab 6: 395-404.

Kreutzberg GW (1996). Microglia: a sensor for pathological events in the CNS. Trends Neurosci 19: 312318. 
Kupfer SR, Summers WC (1990). Identification of a glucocorticoid-responsive element in Epstein-Barr virus. J Virol 64: 1984-1990.

Landfield PW, Baskin RK, Pitler TA (1981). Brain aging correlates: retardation by hormonal-pharmacological treatments. Science 214: 581-584.

Lee JM, Zipfel GJ, Choi DW (1999). The changing landscape of ischaemic brain injury mechanisms. Nature 399(6738 Suppl): A7-A14.

Leech M, Metz C, Hall P, Hutchinson P, Gianis K, Smith M, Weedon H, Holdsworth SR, Bucala R, Morand EF (1999). Macrophage migration inhibitory factor in rheumatoid arthritis: evidence of proinflammatory function and regulation by glucocorticoids. Arthritis Rheum 42: 16011608.

Lefering R, Neugebauer EA (1995). Steroid controversy in sepsis and septic shock: a meta-analysis. Crit Care Med 23: 1294-1303.

Leopardi R, Vainionpaa R, Hurme M, Siljander P, Salmi AA (1992). Measles virus infection enhances IL-1 beta but reduces tumor necrosis factor-alpha expression in human moncytes. J Immunol 149: 2397-2401.

Liao J, Keiser JA, Scales WE, Kunkel SL, Kluger MJ (1995). Role of epinephrine in TNF and IL-6 production from isolated perfused rat liver. Am $J$ Physiol 268(4 Pt 2): R896-R901.

Liles WC, Dale DC, Klebanoff SJ (1995). Glucocorticoids inhibit apoptosis of human neutrophils. Blood 86: 31813188.

Lilly MP, Gann DS (1992). The hypothalamic-pituitaryadrenal-immune axis. Arch Surg 127: 1463-1474.

Limoges J, Persidsky Y, Bock P, Gendelman HE (1997). Dexamethasone therapy worsens the neuropathology of human immunodeficiency virus type 1 encephalitis in SCID mice. I Infect Dis 175: 1368-1381.

Lipton SA, Rosenberg PA (1994). Excitatory amino acids as a final common pathway for neurologic disorders. N Engl J Med 330: 613-622.

Magarinos AM, Deslandes A, McEwen BS (1999). Effects of antidepressants and benzodiazepine treatments on the dendritic structure of CA3 pyramidal neurons after chronic stress. Eur J Pharmacol 371: 113-122.

Marquette C, van Dam AM, Ceccaldi PE, Weber P, Haour F, Tsiang H (1996). Induction of immunoreactive interleukin-1 beta and tumor necrosis factor alpha in the brains of rabies virus infected rats. J Neuroimmunol 68: $45-51$.

Marx J (1995). How the glucocorticoids suppress immunity. Science 270: 232-233.

McEwen BS (1998). Protective and damaging effects of stress mediators. $N$ Engl J Med 238: 171-179.

McEwen BS (2000). The neurobiology of stress: from serendipity to clinical relevance. Brain Res 886: 172189.

McEwen BS, Albeck D, Cameron H, Chao HM, Gould E, Hastings N, Kuroda Y, Luine V, Magarinos AM, McKittrick CR, et al (1995). Stress and the brain: a paradoxical role for adrenal steroids. Vitam Horm 51: 371402.

McEwen BS, De Kloet ER, Rostene W (1986). Adrenal steroid receptors and actions in the nervous system. Physiol Rev 66: 1121-1188.

McEwen BS, Magarinos AM (1997). Stress effects on morphology and function of the hippocampus. Ann $N Y$ Acad Sci 821: 271-284.
McGaugh JL (2000). Memory-a century of consolidation. Science 287: 248-251.

McGeer EG, McGeer PL (1994). Neurodegeneration and the immune system. In: Neurodegenerative disorders. Calne DB (ed). WB Saunders: Philadelphia, PA, pp 277-300.

McGeer EG, McGeer PL (1999). Brain inflammation in Alzheimer disease and the therapeutic implications. Curr Pharm Des 5: 821-836.

McGeer PL, McGeer EG (1995). The inflammatory response system of brain: implications for therapy of Alzheimer and other neurodegenerative diseases. Brain Res Brain Res Rev 21: 195-218.

Meaney MJ (1988). The sexual differentiation of social play. Trends Neurosci 11: 54-58.

Miller G, Davis J (1991). Post-ischemic surge in corticosteroids aggravates ischemic damage to gerbil CA1 pyramidal cells. Soc Neurosci Abst 17: 302.4

Millikan CH, McDowell F, Easton JD (1987). Progressing stroke. In: Stroke. Millikan CH, McDowell F, Easton JD (eds). Lea \& Febiger, Philadelphia, PA, pp 117-130.

Mori N, Prager D (1996). Transactivation of the interleukin1 alpha promoter by the human T-cell leukemia virus type I and type II Tax proteins. Blood 87: 3410-3417.

Mukaida N, Zachariae CC, Gusella GL, Matsushima K (1991). Dexamethasone inhibits the induction of monocyte chemotactic-activating factor production by IL-1 or tumor necrosis factor. J Immunol 146: 1212-1215.

Munck A, Guyre PM, Holbrook NJ (1984). Physiological functions of glucocorticoids in stress and their relation to pharmacological actions. Endocr Rev 5: 25-44.

Munck A, Naray-Fejes-Toth A (1994). Glucocorticoids and stress: permissive and suppressive actions. Ann $N Y$ Acad Sci 746: 115-130.

Nelson DH (1995). Historical overview of the adrenal cortex. In: Endocrinology, vol 3. Degroot L (ed). WB Saunders: Philadelphia, PA, p 257.

Nesathurai S (1998). Steroids and spinal cord injury: revisiting the NASCIS 2 and NASCIS 3 trials. J Trauma 45: 1088-1093.

Neumann H (2001). Control of glial immune function by neurons. Glia 36: 191-199.

Newton CJ, Bilko D, Pappa S, Atkin SL (2001). Dexamethasone blocks antioestrogen- and oxidant-induced death of pituitary tumour cells. J Endocrinol 169: 249-261.

Neznanov N, Kondratova A, Chumakov KM, Angres B, Zhumbayeva B, Agol VI, Gudkov AV (2001). Poliovirus protein $3 \mathrm{~A}$ inhibits tumor necrosis factor (TNF) induced apoptosis by eliminating the TNF receptor from the cell surface. J Virol 75: 10409-10420.

Nguyen KB, Biron CA (1999). Synergism for cytokinemediated disease during concurrent endotoxin and viral challenges: roles for NK and T and IFN-gamma production. J Immunol 162: 5238-5246.

Nishikawa M, Matsubara T, Yoshitomi T, Ichiyama T, Hayashi T, Furukawa S (2000). Abnormalities of brain perfusion in echovirus type 30 meningitis. J Neuro Sci 179(S1-S2): 122-126.

Nishio Y, Isshiki H, Kishimoto T, Akira S (1993). A nuclear factor for interleukin-6 expression (NF-IL6) and the glucocorticoid receptor synergistically activate transcription of the rat alpha 1-acid glycoprotein gene via direct protein-protein interaction. Mol Cell Biol 13: 18541862.

Nogawa S, Zhang F, Ross ME, Iadecola C (1997). Cyclooxygenase-2 gene expression in neurons contributes 
to ischemic brain damage. J Neurosci 17: 27462755.

Noisakran S, Halford WP, Veress L, Carr DL (1998). Role of the hypothalamic pituitary adrenal axis and IL-6 in stress-induced reactivation of latent herpes simplex virus type 1. J Immunol 160: 5441-5447.

Noseworthy JH, Lucchinetti C, Rodriguez M, Weinshenker BG (2000). Multiple sclerosis. N Engl J Med 343: 938952.

Nuovo GJ, Alfieri ML (1996). AIDS dementia is associated with massive, activated HIV-1 infection and concomitant expression of several cytokines. Mol Med 2: 358366.

Olney JW (1978). Neurotoxicity of excitatory amino acids. In: Kainic acid as a tool in neurobiology. McGeer EG, Olney JW, McGeer PL (eds). Raven Press: New York; pp 95-121.

O’Neill LA, Kaltschmidt C (1997). NF-kappa B: a crucial transcription factor for glial and neuronal cell function. Trends Neurosci 20: 252-258.

Ottaviani E, Franceschi C (1996). The neuroimmunology of stress from invertebrates to man. Prog Neurobiol 48: 421-440.

Pascuzzi RM, Coslett HB, Johns TR (1984). Long-term corticosteroid treatment of myasthenia gravis: report of 116 patients. Ann Neurol 15: 291-298.

Pearce BD, Biron CA, Miller AH (2001). Neuroendocrineimmune interactions during viral infections (review). Adv Virus Res 56: 469-513.

Perretti M, Flower RJ (1994). Cytokines, glucocorticoids and lipocortins in the control of neutrophil migration. Pharmacol Res 30: 53-59.

Perry VH, Gordon S (1991). Macrophages and the nervous system. Int Rev Cytol 125: 203-244.

Peterson PK, Gekker G, Hu S, Chao CC (1997). Microglia: a "double-edged sword." In: In defense of the brain. Peterson PK, Remington JS (eds). Blackwell Science: Oxford, UK, pp 31-55.

Pietzko D, Zohlnhofer D, Graeve L, Fleischer D, Stoyan T, Schooltink H, Rose-John S, Heinrich PC (1993). The hepatic interleukin-6 receptor. Studies on its structure and regulation by phorbol 12-myristate 13-acetatedexamethasone. J Biol Chem 268: 4250-4258.

Ransohoff RM, Tani M (1998). Do chemokines mediate leukocyte recruitment in post-traumatic CNS inflammation? Trends Neurosci 21: 154-159.

Rapalino O, Lazarov-Spiegler O, Agranov E, Velan GJ, Yoles E, Fraidakis M, Solomon A, Gepstein R, Katz A, Belkin M, Hadani M, Schwartz M (1998). Implantation of stimulated homologous macrophages results in partial recovery of paraplegic rats. Nat Med 4: 814-821.

Risau W, Wolburg H (1990). Development of the bloodbrain barrier. Trends Neurosci 13: 174-178.

Rothwell NJ, Luheshi G, Toulmond S (1996). Cytokines and their receptors in the central nervous system: physiology, pharmacology, and pathology. Pharmacol Ther 69: 85-95.

Ruscher K, Isaev N, Trendelenburg G, Weih M, Iurato L, Meisel A, Dirnagl U (1998). Induction of hypoxia inducible factor 1 by oxygen glucose deprivation is attenuated by hypoxic preconditioning in rat cultured neurons. Neurosci Lett 254: 117-120.

Ruzek MC, Miller AH, Opal SM, Pearce BD, Biron CA (1997). Characterization of early cytokine responses and an interleukin (IL)-6-dependent pathway of en- dogenous glucocorticoid induction during murine cytomegalovirus infection. J Exp Med 185: 1185-1192.

Ruzek MC, Pearce BD, Miller AH, Biron CA (1999). Endogenous glucocorticoids protect against cytokine-mediated lethality during viral infection. J Immunol 162: 35273533.

Sanderson KL, Raghupathi R, Saatman KE, Martin D, Miller G, McIntosh TK (1999). Interleukin-1 receptor antagonist attenuates regional neuronal cell death and cognitive dysfunction after experimental brain injury. J Cereb Blood-Flow Metab 19: 1118-1125.

Sapolsky RM (1985). A mechanism for glucocorticoid toxicity in the hippocampus: increased neuronal vulnerability to necrotic insults. J Neurosci 5: 1228-1232.

Sapolsky RM (1992). Stress, the aging brain and the mechanisms of neuron death, vol 1. MIT Press: Cambridge, MA, p 423.

Sapolsky RM (1994). The physiological relevance of glucocorticoid endangerment of the hippocampus. Ann NY Acad Sci 746: 294-304; discussion 304-307.

Sapolsky RM (1996). Why stress is bad for your brain. Science 273: 749-750.

Sapolsky RM, Krey LC, McEwen BS (1985). Prolonged glucocorticoid exposure reduces hippocampal neuron number: implications for aging. J Neurosci 5: 12221227.

Sapolsky RM, Pulsinelli WA (1985). Glucocorticoids potentiate ischemic injury to neurons: therapeutic implications. Science 229: 1397-1400.

Sapolsky RM, Rivier C, Yamamoto G, Plotsky P, Vale W (1987). Interleukin-1 stimulates the secretion of hypothalamic corticotropin-releasing factor. Science 238: 522-524.

Sapolsky RM, Romero LM, Munck A (2000). How do glucocorticoids influence stress responses? Integrating permissive, suppressive, stimulatory, and preparative actions. Endocr Rev 21: 55-89.

Sauder C, Wolfer DP, Lipp HP, Staeheli P, Hausmann J (2001). Learning deficits in mice with persisent Borna disease virus infection of the CNS associated with elevated chemokine expression. Behav Brain Res 120: 189201.

Schneider-Schaulies J, Schneider-Schaulies S, Ter Meulen V (1993). Differential induction of cytokines by primary and persistent measles virus infection in human glial cells. Virology 195: 219-228.

Schooltink H, Schmitz-Van de Leur H, Heinrich PC, Rose-John S (1992). Up-regulation of the interleukin-6signal transducing protein (gp130) by interleukin-6 and dexa-methasone in HepG2 cells. FEBS Lett 297: 263265.

Schwartz M, Moalem G (2001). Beneficial immune activity after CNS injury: prospects for vaccination. J Neuroimmunol 113: 185-192.

Segatore M (1999). Corticosteroids and traumatic brain injury: status at the end of the decade of the brain. $J \mathrm{Neu}$ rosci Nurs 31: 239-250.

Selye H (1936). A syndrome produced by diverse nocous agents. Nature 138: 32.

Selye H (1978). The stress of life. McGraw-Hill: New York.

Stein-Behrens BA, Elliott EM, Miller CA, Schilling JW, Newcombe R, Sapolsky RM (1992). Glucocorticoids exacerbate kainic acid-induced extracellular accumulation of excitatory amino acids in the rat hippocampus. $J$ Neurochem 58: 1730-1735. 
Sternberg EM, Hill JM, Chrousos GP, Kamilaris T, Listwak SJ, Gold PW, Wilder RL (1989). Inflammatory mediatorinduced hypothalamic-pituitary-adrenal axis activation is defective in streptococcal cell wall arthritissusceptible Lewis rats. Proc Natl Acad Sci USA 86: 2374-2378.

Stoll G, Jander S, Schroeter M (1998). Inflammation and glial responses in ischemic brain lesions. Prog Neurobiol 56: $149-171$.

Straub RH, Miller LE, Scholmerich J, Zietz B (2000). Cytokines and hormones as possible links between endocrinosenescence and immunosenescence. J Neuroimmunol 109: 10-15.

Takikita S, Takano T, Narita T, Takikita M, Ohno M, Shimada M (2001). Neuronal apoptosis mediated by IL1 beta expression in viral encephalitis caused by a neuroadapted strain of the mumps virus (Kilham strain) in hamsters. Exp Neurol 172: 47-59.

Tanaka J, Ogura T, Kamiya S, Sato H, Yoshie T, Ogura H, Hatano M (1984). Enhanced replication of human cytomegalovirus in human fibroblasts treated with dexamethasone. J Gen Virol 65: 1759-1767.

Thompson KA, Blessing WW, Wesselingh SL (2000). Herpes simplex replication and dissemination is not increased by corticosteroid treatment in a rat model of focal herpes encephalitis. J NeuroVirol 6: 25-32.

Tominaga T, Katagi $\mathrm{H}$, Ohnishi ST (1988). Is $\mathrm{Ca}^{2+}$-activated potassium efflux involved in the formation of ischemic brain edema? Brain Res 460: 376-378.

Trainer PJ, Faria M, Newell-Price J, et al (1995). A comparison of the effects of human and ovine corticotrophinreleasing hormone on the pituitary-adrenal axis. J Clin Endocrinol Metab 80: 412-417.

Tyrrell JB, Aron DC, Forsham PH (1994). Glucocorticoids and adrenal androgens. In: Basic and clinical endocrinology. Greenspan FS, Baxter JD (eds). Appleton and Lange: Norwalk, CT, p 307.

Uz T, Pesold C, Longone P, Manev H (1998). Agingassociated up-regulation of neuronal 5-lipoxygenase expression: putative role in neuronal vulnerability. FASEB J 12: 439-449.

Uz T, Dwivedi Y, Savani PD, Impagnatiello F, Pandey G, Manev H (1999). Glucocorticoids stimulate inflammatory 5-lipoxygenase gene expression and protein translocation in the brain. J Neurochem 73: 693-699.

van der Velden VH (1998). Glucocorticoids: mechanisms of action and anti-inflammatory potential in asthma. Mediators Inflamm 7: 229-237.

Vecht CJ (1998). Clinical management of brain metastasis. J Neurol 245: 127-131.

Vedhara K, Cox NK, Wilcock GK, Perks P, Hunt M, Anderson S, Lightman SL, Shanks NM (1999). Chronic stress in elderly carers of dementia patients and antibody response to influenza vaccination. Lancet 353: 627-631.

Vila N, Castillo J, Davalos A, Chamorro A (2000). Proinflammatory cytokines and early neurological worsening in ischemic stroke. Stroke 31: 2325-2329.

Vincent A, Palace J, Hilton-Jones D (2001). Myasthenia gravis. Lancet 357: 2122-2128.

Vreugdenhil GR, Wijnands PG, Netea MG, van der Meer JW, Melchers WJ, Galama JM (2000). Enterovirusinduced production of pro-inflammatory and T-helper cytokines by human leukocytes. Cytokines 12: 17931796.

Walker DG, Kim SU, McGeer PL (1995). Complement and cytokine gene expression in cultured microglial derived from postmortem human brains. J Neurosci Res 40: 478493.

Wekerle H, Linington C, Lassmann H, Meyermann R (1986). Cellular immune reactivity within the CNS. Trends Neurosci 9: 271-277.

Whetsell WO Jr (1996). Current concepts of excitotoxicity. J Neuropathol Exp Neurol 55: 1-13.

Wiegers GJ, Reul JM (1998). Induction of cytokine receptors by glucocorticoids: functional and pathological significance. Trends Pharmacol Sci 19: 317-321.

Wilckens T, De Rijk R (1997). Glucocorticoids and immune function: unknown dimensions and new frontiers. Immunol Today 18: 418-424.

Yamabe T, Dhir G, Cowen EP, Wolf AL, Bergey GK, Krumholz A, Barry E, Hoffman PM, Dhib-Jalbut S (1994). Cytokine-gene expression in measles-infected adult human glial cells. J Neuroimmunol 49: 171-179.

Yamamura M, Yamada Y, Momita S, Kamihira S, Tomonaga M (1998). Circulating interleukin-6 levels are elevated in adult T-cell leukaemia/lymphoma patients and correlate with adverse clinical features and survival. $\mathrm{Br} J$ Haematol 100: 129-134.

Yoles E, Hauben E, Palgi O, Agranov E, Gothilf A, Cohen A, Kuchroo V, Cohen IR, Weiner H, Schwartz M (2001). Protective autoimmunity is a physiological response to CNS trauma. J Neurosci 21: 3740-3748.

Zidovetzki R, Wang JL, Chen P, Jeyaseelan R, Hofman F (1998). Human immunodeficiency virus Tat protein induces interleukin 6 mRNA expression in human brain endothelial cells via protein kinase $\mathrm{C}$ and Camp dependent protein kinase pathways. AIDS Res Hum Retrovir 14: 825-833.

Zuckerman SH, Shellhaas J, Butler LD (1989). Differential regulation of lipopolysaccharide-induced interleukin 1 and tumor necrosis factor synthesis: effects of endogenous and exogenous glucocorticoids and the role of the pituitary-adrenal axis. Eur J Immunol 19: 301-305. 